ACTA MYCOLOGICA

Vol. 43 (2): 207-213

2008
It is our great pleasure to dedicate

this paper to Professor Krystyna Czyżewska

on the occasion of her anniversary

\title{
Is a remarkable species - Caloplaca flavescens (lichenized fungi) - new to the Polish lichen biota?
}

\author{
LUCYNA ŚLIWA and KARINA WILK
}

\begin{abstract}
Laboratory of Lichenology, W. Szafer Institute of Botany, Polish Academy of Sciences Lubicz 46, PL-31-512 Kraków, l.sliwa@botany.pl; k.wilk@botany.pl
\end{abstract}

Śliwa L., Wilk K.: Is a remarkable species - Caloplaca flavescens (lichenized fungi) - new to the Polish lichen biota? Acta Mycol. 43(2): 207-213, 2008.

Caloplaca flavescens is reported for the first time from Poland with all known localities citation. Diagnostic characters for the species are narrow, convex marginal lobes that are separated by furrows and gray crystals within the thallus cortex that are prominent in polarized light as well as lemon-shaped ascospores. Species of similar appearance include $C$. aurantia, C. thallinicola and some members of $C$. saxicola group. Differences between these species are briefly discussed. An up-to-date distribution map for $C$. flavescens in Poland is presented.

Key words: lichens, Caloplaca, new records

\section{INTRODUCTION}

Caloplaca flavescens (Huds.) J.R. Laundon is a member of the lobate species of the genus Caloplaca and it is included in the subgenus Gasparrinia Tornab. defined as having lobate thallus and containing anthraquinones (giving $\mathrm{K}+$ violet-red reaction) and it is included in the group $C$. aurantia characterized by lemon-shape ascospores. The species is distinctive due to narrow, convex marginal lobes that are separated by furrows and gray cortical crystals that are prominent in polarized light. It is calcicolous lichen occurring most often on limestone outcrops.

The nomenclature and taxonomic position of the species was established by Laundon (1984). Clauzade and Roux (1985) contributed significantly to the understanding of the species and provided its circumscription and excellent demonstrative illustrations. The species was detailed treated and widely discussed in the most recent revision of $C$. aurantia group in the Czech Republic by Šoun (2005) and in the monograph of lobate species of Caloplaca with a special reference to C. saxicola group in Europe by Gaya (2005).

The taxon was noted for the first time from Poland by Nowak and Tobolewski (1975) under the name Caloplaca aurantia var. heppiana (Müll. Arg.) Poelt, however, no data was quoted regarding collecting site of this particular variety and no 
such material was found at KRAM herbarium. Under the species name Caloplaca flavescens the taxon was recognized for the first time during lichenological studies of the Krakowsko-Częstochowska Upland by J. Nowak in 1986 and of the Beskid Sądecki range in the Polish Western Carpathians by L. Śliwa in 1992. The species was collected from single localities and the specimens were housed in KRAM and KRA herbaria respectively. The records, however, have never been published as they were considered by the collectors as uncertain. The determination was confirmed by C. Wetmore in 1997. While visiting KRAM herbarium at the same time Wetmore revised the material of $C$. aurantia group and majority of the collection was re-identified as $C$. flavescens. Moreover, during a joint field trips with $\mathrm{L}$. Śliwa to different parts of southern Poland he collected the species himself and the material is housed at MIN herbarium. Based on the above collections the species was included in the checklists of the Western Carpathians (Bielczyk 2003; Bielczyk et. al. 2004) and subsequently indicated in the recent Polish checklist (Fałtynowicz 2003). No information concerning collecting sites were provided in any of the publications. During the recent study of calcicolous species of Caloplaca in the Polish Western Carpathians by K. Wilk all material was revised and some new localities of $C$. flavescens were found (Wilk 2008). The species appeared much easier determinable but based primarily on some anatomical characters and more frequent than it was considered before.

The main purpose of this account is to make the status of $C$. flavescens in Poland clear and to encourage lichenologists to pay special attention to this remarkable species.

\section{MATERIAL AND METHODS}

Apart from the authors' collections, reference materials of Caloplaca aurantia (Pers.) Hellb., C. flavescens (Huds.) J.R. Laundon and C. saxicola complex from the herbaria KRA, KRAM, and KRAP were investigated.

For light microscopy, free-hand sections were made with a razor blade and mounted in water. Tissue and ascospore measurements were made in water. Measurements are rounded to the nearest 0.5 microns. Granulation of tissues was observed in polarized light. The solubility of granules or/and crystals was tested with ca $25 \% \mathrm{KOH}(\mathrm{K})$ and $65 \%$ nitric acid $(\mathrm{N})$; these last two reagent tests were always carried out on separate cross sections. Spot test reactions of thalli, apothecial margins and discs were made with the same reagents.

\section{DESCRIPTION OF THE SPECIES}

Caloplaca flavescens (Huds.) J.R. Laundon, Lichenologist 16: 53. (1984). Figs $1 \mathrm{~A}, 2 \mathrm{~A}, 3 \mathrm{~A}$

Basionym: Lichen flavescens Huds., Fl. Anglica: 445. 1762. Type: Hist. Musc.: 136, tab. 18, fig. $18 A$ (BM - lectotype, not seen).

Selected synonyms: Caloplaca heppiana (Müll. Arg.) Zahlbr.; Amphiloma heppianum Müll. Arg. Caloplaca aurantia var. heppiana (Müll. Arg.) Poelt [for details see Laundon 1984]. 
Thallus placodioid, forming closely adpressed rosettes up to $3 \mathrm{~cm}$ in diameter; rosettes of thalli single or grouped, yellowish orange or deep orange, sometimes blanched in the central part of thallus, especially if growing in the deep shadow, epruinose or faintly pruinose; lobes at the margin of thallus 5-10 $\mathrm{mm}$ long and 0.3 $0.5 \mathrm{~mm}$ wide, deeply and dense incised, narrow and convex, separated by furrows, lobe-ends slightly broader and indented; center of thallus with uneven, irregular and often convex areoles; cortex thick, prosoplectenchymatic with thick layer of coarse, gray crystals (prominent in polarized light, insoluble in $\mathrm{K}$ and slowly soluble in $\mathrm{N}$ ); algae layer discontinuous, algae cells clustered into groups; medulla prosoplectenchymatic, without crystals. Apothecia up to $1.2 \mathrm{~mm}$ diam., mainly confined to the centre of the thallus, usually abundant, dispersed or crowded, regular in shape or angular and flexuose due to compression; disc flat to convex, deep orange to orange brownish, epruinose; true exciple thin, prominent or level with the disc, smooth, paler than disc; thalline exciple soon excluded, sometimes visible at the base of the apothecium. Amphithecium lowered, algae abundant, cortex \pm thick, paraplectenchymatie; parathecium well developed, distinct, prosoplectenchymatic; epihymenium granular, golden brown; hymenium hyaline, 80-115 $\mu \mathrm{m}$ high; hypothecium hyaline, prosoplectenchymatic, with numerous oil droplets. Paraphyses thick, up to $2.5 \mu \mathrm{m}$ wide, simple or faintly branched at the top, not expanded, or slightly expanded apically. Spores broad, lemon-shaped, 8-15 × 6-11.5 $\mu \mathrm{m}$, septum (2-)3-4 $\mu \mathrm{m}$, 8 per ascus. Pycnidia often abundant, orange, immersed; conidia simple, straight, colorless, $3.5-5.5(-7.5) \times 1 \mu \mathrm{m}$.

SPOT TEST REACTIONS. Thallus and apothecia $\mathrm{K}+$ violet-red, $\mathrm{N}-$; medulla $\mathrm{K}-$, $\mathrm{N}-$; epihymenium $\mathrm{K}+$ violet-red.

Discussion. Caloplaca flavescens can be rather easily distinguished by long, narrow and convex marginal lobes and spores that are lemon-shaped. Moreover, the thallus cortex of the species is obscured by wide layer of grey crystals (Fig. 2A) that are prominent in polarized light (Fig. 3A). Due to these character it is rather unlikely to be mistaken with any other Caloplaca member. The species is mostly related to $C$. aurantia (Fig. 1B). The latter species, however, lacks crystals in the thallus cortex (Figs 2B, 3B). The thalline lobes of $C$. aurantia are flat and distinctly broader at the ends and closely attached one to the other. Moreover, the species is lighter and often zonated in colour. Both species are widely discussed by Soun (2005) and Gaya (2005).

Representatives of $C$. saxicola complex have much smaller thallus with considerable shorter lobes that are often pruinose or scabrid. The members of the group have also ellipsoid spores. Most of species of the group differ also in habitat preferences.

Another similar taxon is $C$. thallinicola (Wedd.) Du Rietz. It differs from $C$. flavescens by very elongated lobes, deeper furrows between lobes and cortical crystals clustered into spherical, separated groups (see Clauzade \& Roux 1985). Most of all, however, the species differs in ecology. It occupies maritime acid and calcareous rocks.

REMARKs. As a result of $C$. flavescens delimitation a distribution of $C$. aurantia in Poland is in need of urgent revision. The species is most likely more rare than indicated in bibliographic sources. 


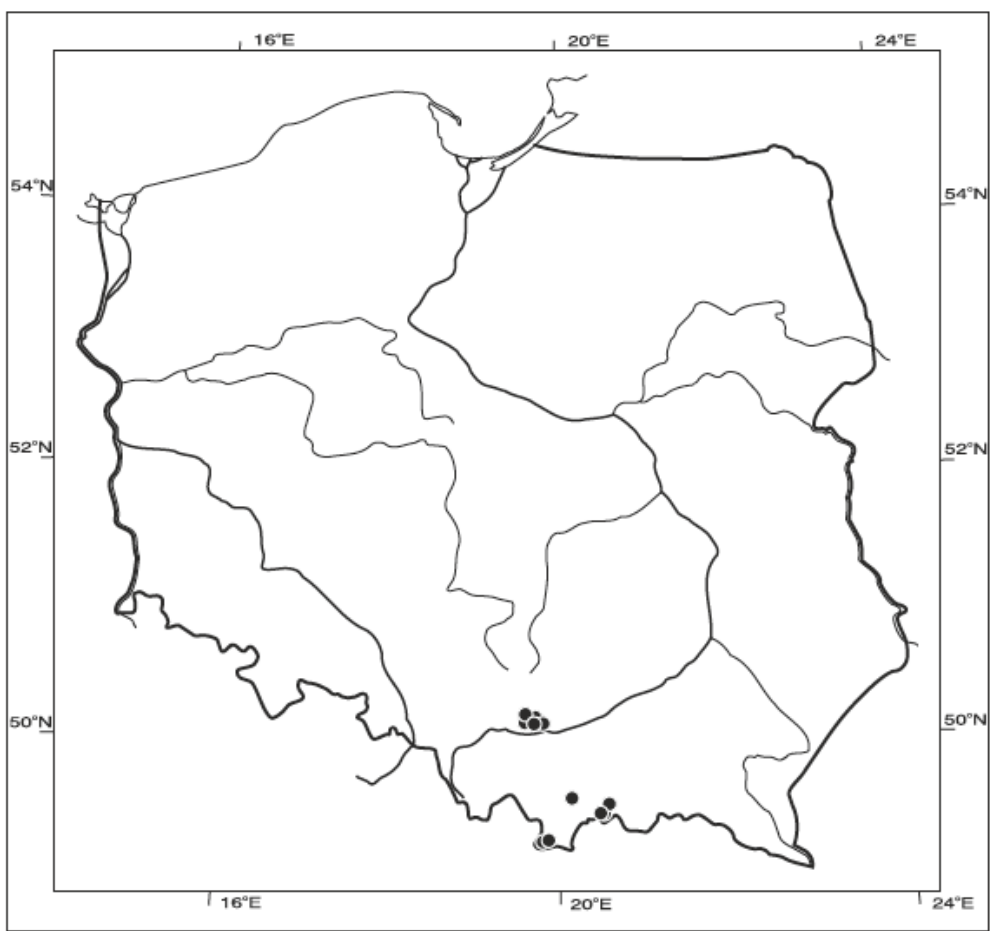

Fig. 4. Known distribution of Caloplaca flavescens in Poland.

НАBITAT. The species occurs on calcareous rocks and most often on limestone in open, sunny and dry situations. Rarely it was noted in moderately shaded sites. It occupies vertical and overhanged rocks of various exposure: $\mathrm{N}, \mathrm{NW}, \mathrm{S}$. The species grows at the base but also in the uppermost parts of the rocks. Caloplaca flavescens prefers natural habitats but it was also found on a fence made of calcareous sandstone. The species usually occurs abundantly, forming populations of numerous individuals.

Distribution In Poland. The disjunctive range of the species coincides with the location of calcareous habitats in southern Poland (Fig. 4). It occurs in the Krakowsko-Częstochowska Upland where it is relatively frequent. The species seems also spread in the Carpathians Mts. Most records originate from the Pieniny Mts. and the Western Tatry Mts. where calcareous rocks are most often. In the other parts of the mountain range the species seems rather rare; so far it was found only in the Beskid Sądecki and in the Carpathians foothills.

WORLD DISTRIBUTION. The species occurs in Mediterranean, Atlantic and Central parts of European Continent including Balcan Peninsula - Austria: Hafellner and Türk (2001); Belgium and Luxembourg: Diederich and Sérusiaux (2000); Bulgaria: Mayrhofer et al. (2005); Czech Republic: Šoun (2005); France: Clauzade and Roux (1985); see also Laundon (1984); Germany: Wirth (1995); Great Britain and Ireland: Coppins (2002); Italy: Nimis (1993); Nimis and Martellos (2003); Iberian Peninsula and Balearic Islands: Llimona and Hladun (2001); Romania: Ciurchea (1998); Slovakia: Pišút et al. (1996); Ukraine: Kondratyuk et al. (1996a, 2003), as 
well as in Scandinavian countries (Norway and Sweden: Santesson et al. 2004). It was also reported from Near and Middle East (Israel: Kondratyuk et al. 1996b; Turkey: John 1996) and northern Africa (Egypt: Seaward and Sipman 2006; Morocco: Egea 1996; Tunisia: Seaward 1996). According to Šoun (2005) it was also recorded in Canary Islands, Azores and European part of Russia.

Specimens examined. Poland. Carpathians: Beskid Sądecki Mts., Pasmo Radziejowej, Szlachtowa, alt. $550 \mathrm{~m}$, fence made of calcareous sandstones, 2 May 1991, L. Śliwa s.n. (KRA); Pieniny Mts., Wąwóz Homole canyon, 49²3'54”N/20³3'20”E, 30 Aug. 2000, C. Wetmore 85268 (MIN); Pieniny Małe Mts.: "Biała Woda", calcareous rock on right bank of a stream, near old sheepfold, 1 June 1999, J. Kiszka s.n. (KRAP); Dziobakowe Skały rocks, SE of Jaworki village, alt. $738 \mathrm{~m}, 49^{\circ} 23$ '21' $\mathrm{N} / 20^{\circ} 34^{\prime} 05^{\prime}$ 'E, large limstone outcrops in a mixed forest, 4 June 2005, K. Wilk 3429, 3435 (KRAM); near Jaworki village, limstone outcrops along bike trail, alt. 580 m, 49²4'20’N/20³2'30'”, 3 June 2005, K. Wilk 3423 (KRAM); Podhale foothills, Skalice Nowotarskie, N slope of Kramnica Mt., calcareous rock, alt. 640 m, 24 June 1968. J. Kiszka s.n. (KRAP); Tatry Zachodnie Mts.: Dolina Kościeliska valley, $3 \mathrm{~km} \mathrm{SW}$ of Zakopane, 49¹4’30"N/1951'46”E, 9 May 1997, C. Wetmore 77318 (MIN); Dolina Kościeliska valley, near Wyżnia Pisana Polana glade, vertical calcareous rock, alt. ca 1100 m, 13 July 2004, K. Wilk 2129; Wąwóz Kraków canyon, vartical calcareous rock, alt. ca 1100 m, 15 July 2004, K. Wilk 2147, 2149 (KRAM). Wyżyna Krakowsko-Częstochowska Upland: Limestone quarry, $12 \mathrm{~km} \mathrm{NW}$ of Krakow, along a road to Olkusz, 5009'12”N/1947'06”E, 6 May 1997, C. Wetmore (MIN); Dolina Będkowska valley, alt. 380 m, vertical limestone rocks, 1 May 1956, J. Nowak (KRAM-L 18770); Dolina Kluczwody valley, at the base of vertical limestone rocks, 19 Dec. 1992, J. Nowak (KRAM-L 31608), Zamkowa rock, alt. $320 \mathrm{~m}$, in a bottom of the valley, at the base of vertical limestone rock, 15 June 1994, J. Nowak (KRAM-L 28036); Dolina Kobylańska valley, Kula rock, alt. $350 \mathrm{~m}$, vertical limestone rock, in a sunny place, 2 May 1995, J. Nowak (KRAM-L 40213); Nielepice village near Rudawa, 6 km EES of Krzeszowice town, N-facing, open slope of Chełm hill, alt. $280 \mathrm{~m}$, on vertical or overhanged limestone outcrops, 30 Sept. 1986, J. Nowak (KRAM-L 30454).

Additional specimens examined. Bulgaria. Czarnatica. Bielocerkowski Rid, Biala Cerkwa, alt. 1300 m, calcareous rocks, 29 Sept. 1975, J. Nowak (KRAM-L 34966, 34968). Slovakia. Spisz, Drevenik near Spissky Hrad, alt. 600 m, calcareous rocks, 3 July 1993, U. Bielczyk (KRAM-L 23972).

Acknowledgements. Sincere thanks are due to Prof. Dr. Clifford M. Wetmore (University of Minnesota, USA) for confirmation or revision of some Polish collections. We are grateful to the anonymous reviewer for valuable suggestions on the manuscript. The study was supported by the Ministry of Science and Higher Education, grant no. N303 294334.

\section{REFERENCES}

Bielczyk U. 2003. The lichens and allied fungi of the Polish Western Carpathians. (In:) U. Bielczyk (ed.), The lichens and allied fungi of the Polish Carpathians - an annotated checklist. W. Szafer Institute of Botany, Polish Academy of Sciences, Kraków: 23-232.

Bielczyk U., Lackovičová A., Farkas E., Lőkös L., Liška J., Brouss O., Kondratyuk S. Ya. 2004. Checklist of lichens of the Western Carpathians. W. Szafer Institute of Botany, Polish Academy of Sciences, Kraków, $181 \mathrm{pp}$. 
Clauzade G., Roux C. 1985. Likenoj de okcidenta Eŭropo. Ilustrita determinlibro. Bull. Soc. Bot. CentreOuest, Numero Special 7. Royan, France, 893 pp.

Coppins B.J. 2002. Checklist of lichens of Great Britain and Ireland. British Lichen Society, 87 pp.

Ciurchea M. 1998. Catalog of lichens in Romania. Available at http://ichens.duci.ro/Catalog.htm, date of exploration: 20 October 2008.

Diederich P., Sérusiaux E. 2000. The lichens and lichenicolous fungi of Belgium and Luxembourg. An annotated checklist. Musée national d'histoire naturelle, Luxembourg, 208 pp.

Egea J.M. 1996. Catalogue of lichenized and lichenicolous fungi of Marocco. Bocconea 6: 19-114.

Fałtynowicz W. 2003. The lichens, lichenicolous and allied fungi of Poland. An annotated checklist. W. Szafer Institute of Botany, Polish Academy of Sciences, Kraków, 435 pp.

Gaya E. 2005. Revisió morfològica i molecular dels tàxons lobulats del gènere Caloplaca (Teloschistaceae, liquens), amb especial èmfasi en el grup de C. saxicola. Doctoral thesis, University of Barcelona. 419 pp. Available at http://www.tesisenxarxa.net/, date of exploration: 20 October 2008.

Hafellner J., Türk R. 2001. Die lichenisierten Pilze Österreichs - eine Checkliste der bisher nachgewiesenen Arten mit Verbreitungsangaben. Stapfia 76: 3-173.

John V. 1996. Preliminary catalogue of lichenized and lichenicolous fungi of Mediterranean Turkey. Bocconea 6: 173-216.

Kondratyuk S.Ya., Navrotskaya I., Khodosovtsev A.Ye., Solonina O. 1996a. Checklist of Ukrainian lichens. Bocconea 6: 217-294.

Kondratyuk S.Ya., Zelenko S.D., Wasser S.P., Nevo E. 1996b. The first checklist of lichen-forming and lichenicolous fungi of Israel. M.H. Kholodny Institute of Botany, National Academy of Sciences of Ukraine \& International Centre for Cryptogamic Plants and Fungi, Kiev, Haifa, 136 pp.

Kondratyuk S.Ya., Popova L.P., Lackovičová A., Pišút I. 2003. A catalogue of Eastern Carpathian lichens. M.H. Kholodny Institute of Botany, National Academy of Sciences of Ukraine \& Institute of Botany, Slovak Academy of Sciences, Kiev, Bratislava, 263 pp.

Laundon J.R. 1984. Studies in the nomenclature of British lichens I. Lichenologist 16 (1): 53-57.

Llimona X., Hladun N.L. 2001. Checklist of the lichens and lichenicolous fungi of the Iberian Peninsula and Balearic Islands. Bocconea 14: 5-581.

Mayrhofer H., Denchev C.M., Stoykov D.Y., Nikolova S.O. 2005. Catalogue of the lichenized and lichenicolous fungi in Bulgaria. Mycologia Balcanica 2(1): 3-61.

Nimis P.L. 1993. The lichens of Italy. An annotated catalogue. Museo Regionale di Scienze Naturali, Monografie 12, Torino, $897 \mathrm{pp}$.

Nimis P.L., Martellos S. 2003. A second checklist of the lichens of Italy with a thesaurus of synonyms. Museo Regionale di Scienze Naturali, Monografie 4, Aosta, 4192 pp.

Nowak J., Tobolewski Z. 1975. Porosty polskie. Opisy i klucze do oznaczania porostów w Polsce dotychczas stwierdzonych lub prawdopodobnych. Państwowe Wydawnictwo Naukowe, Warszawa-Kraków, $1177 \mathrm{pp}$.

Pišút I., Lackovičová A., Lisická E. 1996. A second checklist and bibliography of Slovak lichens. Biologia, Bratislavia, 51/Supplement 3: 1-79.

Santesson R., Moberg R., Nordin A., Tønsberg T., Vitikainen O. 2004. Lichen-forming and lichenicolous fungi of Fennoscandia. Museum of Evolution, Uppsala University, Uppsala, Sweden, 359 pp.

Seaward M.R.D. 1996. Checklist of Tunisian lichens. Bocconea 6: 115-148.

Seaward M.R.D., Sipman H. 2006. An updated checklist of lichenized and lichenicolous fungi for Egypt. Willdenowia 36: 537-555.

Šoun J. 2005. Revize skupiny Caloplaca aurantia v Ceské republice Mgr. Thesis, Faculty of Biological Sciences, University of South Bohemia, Ceské Budejovice, Czech Republic, 46 p., + 2 p. Suppl., Available at http://botanika.bf.jcu.cz/thesis/pdf/Soun2005.pdf, date of exploration: 20 October 2008.

Wilk K. 2008. Kalcyfilne gatunki rodzaju Caloplaca w polskich Karpatach Zachodnich. Doctoral thesis, W. Szafer Institute of Botany, Polish Academy of Sciences, Kraków, 158 pp.

Wirth V. 1995. Die Flechten Baden-Württembergs, Teil 1 \& 2. Eugen Ulmer GmbH \& Co., Stuttgart, $1006 \mathrm{pp}$. 
Czy Caloplaca flavescens jest gatunkiem nowym dla bioty porostów Polski?

\section{Streszczenie}

Caloplaca flavescens (Huds.) J.R. Laundon (Fig. 1A) reprezentuje grupę Caloplaca ujętych w podrodzaju Gasparrinia, wytwarzających zewnętrzną łatkowatą plechę i zawierających antrachinony. Jest to porost kalcyfilny, występujący na wychodniach skał wapiennych.

W Polsce gatunek ten był wyróżniony dawno temu i choć w literaturze powoływano się na okazy zielnikowe to nigdy nie został właściwie opublikowany. Tutaj gatunek $C$. flavescens jest po raz pierwszy odnotowany z Polski i udokumentowany materiałami zielnikowymi. Ponadto podano jego charakterystykę i porównano z gatunkami, z którymi może być mylony - z C. aurantia (Fig. 1B), grupą C. saxicola oraz C. thallinicola.

Caloplaca flavescens charakteryzuje się długimi, wąskimi i wypukłym łatkami, które są oddzielone głębokimi szczelinami. Zarodniki $C$. flavescens mają cytrynowaty kształt a kora plechy wypełniona jest szeroką warstwą szarych kryształów świecących w świetle spolaryzowanym (Figs 2A, 3A). Najbliżej gatunek ten jest spokrewniony z C. aurantia. Łatki plechy C. aurantia są płaskie, wyraźnie szersze na końcach i ściśle do siebie przylegające. Cechą diagnostyczną dla tego gatunku jest także brak wyżej opisanych kryształów w korze (Fig. 2B, 3B). Przedstawiciele grupy $C$. saxicola mają mniejszą plechę, znacznie krótsze, często przyprószone łatki oraz posiadają elipsoidalne zarodniki. Innym podobnym taksonem jest $C$. thallinicola. Gatunek ten różni się od $C$. flavescens bardzo wydłużonymi łatkami oraz głębokimi szczelinami pomiędzy nimi, jak również kryształami w korze plechy, które łączą się w kuliste skupienia. Ponadto gatunek ten zajmuje odmienne siedlisko, mianowicie występuje na skałach morskich, zarówno kwaśnych jak i zawierających węglan wapnia.

W pracy omówiono także siedliska zajmowane przez C. flavescens, znane rozmieszczenie tego gatunku w Polsce (Fig. 4) oraz jego ogólny zasięg występowania. 